\title{
A Study on Cultural Difference of Working Values of Chinese Managers and Filipino Managers: A Case of Philippine Company in China
}

\author{
Min Zheng*, Hanjun Li, Bo Yin, Wenju Liu \\ College of Business Administration, University of the Cordilleras, Baguio City, Philippines \\ Email: *xiaojun728@163.com
}

How to cite this paper: Zheng, M., Li, H. J., Yin, B., \& Liu, W. J. (2020). A Study on Cultural Difference of Working Values of Chinese Managers and Filipino Managers: A Case of Philippine Company in China. Open Journal of Social Sciences, 8, 465-474. https://doi.org/10.4236/jss.2020.86036

Received: May 22, 2020

Accepted: June 25, 2020

Published: June 28, 2020

Copyright $\odot 2020$ by author(s) and Scientific Research Publishing Inc. This work is licensed under the Creative Commons Attribution International License (CC BY 4.0).

http://creativecommons.org/licenses/by/4.0/ (c) (i) Open Access

\begin{abstract}
In recent years, more and more multinational enterprises participate in the rapid development of China's economy. Among them, Philippine enterprises have also begun to accelerate the pace of investment and factory building in China. The investment area also extends from the coast to the mainland. With the expansion of enterprise scale and the improvement of employee diversity, the cultural differences between China and Philippines in Philippine enterprises began to highlight, resulting in a serious trend of cultural conflict. $\mathrm{Hu}$ man resource management based on cultural differences has gradually become the primary task that Philippine enterprises in China must deal with. Firstly, the study defines the basic concepts and reviews related literature. Secondly, the research starts to study the society formation, economic institution and history background of these two countries. Thirdly, the research discusses the internal cultural differences focusing on the working values and needs of employees from two different countries and suggests recommendations. Lastly, through the further research, the study determines the most important culture conflict issues occur in Philippine Company in China and suggests measures to resolve culture conflicts. From the perspective of cultural core, the research is aimed to compare and contrast characteristics and working values of Chinese managers and Filipino managers using Hofstede's cultural five-dimensional theory. Questionnaire and case analysis methods are adopted in the research.
\end{abstract}

\section{Keywords}

Working Values, Pinoy Managers, Chinese Managers, Hofstede’s Cultural 


\section{Introduction}

China and the Philippines, both of which belong to the Confucian cultural circle, have experienced centuries of long-term exchanges and barriers. Because of their different historical development directions, the two countries differ greatly in ideology, values, attitudes and behavior (Amante, 1994). At the same time, because they have received different education for a long time, they live in different political and economic systems, and have different life and work experience and different ways of thinking. Therefore, Philippine managers and Chinese managers have different attitudes towards work and achievement.

\section{Literature Review}

Peter Drucker, a famous American management scholar, first explicitly pointed out the relationship between management and culture in his book Management. He sees culture in the discipline of management and believes that management has its own values, beliefs and language, functions hidden in the traditions of values, customs and beliefs, and in the political system of government. Therefore, he concluded that management is restricted by culture.

Hofstede's "Onion Skin Theory" holds that the influence of culture on enterprise management can be divided into four levels from inside to outside, and each concept can be generalized by four nouns: symbol, hero, etiquette and values, each noun represents a level (Hofstede, 2001). The external factors are easy to observe, easy to express and grasp through practice; the internal values are difficult to observe, relatively stable. For multinational corporations, each layer is colorful, composed of elements from different cultures, implying the danger of cultural conflict. Management tries to understand culture, influence culture, avoid cultural differences and penetrate into the core level by going deep into the practice of the onion center.

\section{The Study}

According to the actual conditions, our research adopts the methods of behavior observation and measurement, case study and comparative study. Among them, the design of the questionnaire refers to the relevant research of Hofstede and others, and designs a questionnaire for the personnel of China and the Philippines. Philippine managers play a key role in the investment and development of Philippine enterprises in China, however, these Philippine managers are most likely to have cross-cultural conflicts with Chinese employees in different cultural backgrounds. For this reason, we applied Hofstede's theory of Five Dimensions of Culture to make a research questionnaire on the work values of employees (Luo, 2001). 125 copies of the questionnaire were sent to Chinese and 
Philippine people respectively, 215 of which were recovered. 113 copies of the valid questionnaires were from China and 98 from the Philippines. The case study selects SM China, a typical representative of Philippine enterprises in China, to collect and analyze data.

\section{Compare and Contrast of Characteristics and Working Values of Chinese Managers and Filipino Managers}

\section{1) Characteristics and working values of Chinese managers}

Our team used Hofstede's cultural five-dimensional theory to make a questionnaire to compare and investigate the work values of Chinese managers and Philippine managers. According to the design of the questionnaire, the investigation was carried out among Chinese and Philippine managers. The results show that the working values of Chinese managers have several characteristics. First, the power distance index is high. As long as there is a possibility of fair mobility in the class system, the fact that Chinese managers have uneven power is based on respect and acceptance. Secondly, the high uncertainty avoidance index indicates that Chinese managers have psychological fears and a considerable lack of security, so it is desirable that the management norms of the organization be very clear. Third, the individualism index is lower than the world average and lower than the Philippines, indicating that Chinese managers still prefer collectivism. Fourthly, in terms of the masculinity index of values, Chinese managers show feminine tendencies, which shows that they attach more importance to interpersonal relationships, while dominance and dogmatism are lower. The statistics are showing in Table 1.

It can be seen that the main incentive for Chinese managers to work is to learn professional skills and management, followed by self-esteem and self-realization, which is reflected in the pursuit of a high degree of salary and rights requirements.

Statistical data showing in Table 2 show that Chinese employees accept the existence of greater power distance, which is mainly reflected in respect of the social reality of uneven power in reality, a high degree of obedience to command and control. Unlike the institutional power distance in the Philippines, this obedience is based on "people" and is particularly influenced by the charisma of leaders. Without violating the principles, leaders have the right of making decisions. So it is particularly important to establish good personal relations with leaders in China.

Table 1. Main working reasons of Chinese managers.

\begin{tabular}{cc}
\hline main reasons of working & Chinese managers \\
\hline salaries & $34.3 \%$ \\
working makes life more meaningful & $50.0 \%$ \\
learning techniques and management & $57.8 \%$ \\
establishing relationship & $15.6 \%$ \\
preparation for future entrepreneurship & $7.8 \%$ \\
\hline
\end{tabular}


Table 2. Reasons of following leadership in China.

\begin{tabular}{cc}
\hline reasons of following leadership & Chinese managers \\
\hline respecting the noble character of leaders & $64.0 \%$ \\
respecting professional knowledge of leaders & $43.8 \%$ \\
leaders have the power to influence personal interests & $39.0 \%$ \\
reverence for leadership & $28.1 \%$ \\
good relationship with leaders & $29.7 \%$ \\
\hline
\end{tabular}

\section{2) Characteristics and working values of Philippine managers}

To study the management of Filipino managers, first of all, we need to study and understand their work values, because values will affect the attitude and behavior of Filipino managers.

Compared with Chinese managers, Filipino managers' work values have several characteristics. First, the long-term orientation index is much lower than that of Chinese managers. Philippines has a large number of incomplete contracts with incomplete employment (Underemployment). Employee job hopping is more common, and they are not in favor of working in a company for a long time. Second, the tendency of individualism is slightly higher, which is close to Spain and the United States, and is not used to collectivism. Thirdly, the great disparity in power is mainly due to years of colonial rule and autocratic rule after independence in the Philippines. Fourth, uncertainty avoidance is relatively high, which is close to Fujian merchant culture. The statistics are showing in Table 3.

According to Maslow's demand theory, earning wages and meeting the basic three meals together constitute the lowest level of demand, a total of $24 \%$, constituting one of the main job incentives for Filipino managers, which is the same for Chinese managers. On the future entrepreneurship issue, Chinese and Philippine management personnel show quite different discrepancy. It is obvious from the questionnaires that most Philippine managers' long-term development aims at accumulating funds for entrepreneurship. In conversations with Filipino managers, they often experience the entrepreneurial spirit of "preferring to be a chicken's head rather than a phoenix's tail", rather than the legacy of the state-owned enterprises in which Chinese employees seek stable income and stable housing.

Statistics showing in Table 4 show that Filipino employees, like China, accept greater power distances and respect the social reality of power inequality and obey command. However, influenced by the modern western commercial culture, they will distinguish the work from the life. While accepting leadership, they generally do not develop personal relationships with the leader. The main reason for obeying leadership is work. The noble style that has nothing to do with work does not add points to obeying the leader more at work. Chinese employees have a sense of attachment, they seek protection from their leaders in obedience, and thus have a high degree of loyalty. In Philippines degree of individualism is higher than that in China, for Pinoy managers, obedience is based 
Table 3. Main working reasons of Filipino managers.

\begin{tabular}{cc}
\hline main reasons of working & Filipino managers \\
\hline salaries & $24.0 \%$ \\
working makes life more meaningful & $30.0 \%$ \\
learning techniques and management & $52.3 \%$ \\
establishing relationship & $11.2 \%$ \\
preparation for future entrepreneurship & $31.3 \%$ \\
\hline
\end{tabular}

Table 4. Reasons of following leadership in Philippines.

\begin{tabular}{cc}
\hline reasons of following leadership & Pinoy managers \\
\hline respecting the noble character of leaders & $23.2 \%$ \\
respecting professional knowledge of leaders & $53.3 \%$ \\
leaders have the power to influence personal interests & $8.7 \%$ \\
reverence for leadership & $3.4 \%$ \\
good relationship with leaders & $8.0 \%$ \\
\hline
\end{tabular}

on system as an independent person, they don't have the existence of inner compulsory.

\section{Implications and Conclusions}

1) Conventional comparisons of the Eastern and the Western countries have either implicitly or explicitly assumed that all Asian countries are similar and therefore can be culturally grouped and labeled the Eastern or Oriental culture (Zhang, Mathur, \& Neelankavil, 2000). Contrary to this assumption, sufficient differences in managerial perceptions across Philippines and China prevent us from making such an assertion, particularly with regard to managerial practices. For example, we found that Filipino managers showed marked differences from Chinese managers with respect to planning/decision making, educational achievement, and past experience. Differences can be accounted for by the historical contexts within which these cultures have evolved (Yan, 2008). While the Chinese culture was isolated from outside influence for a very long time, Filipino cultures have had outside influence for a very long time. This study supports the view that cultural values, such as collectivism/individualism, impact managerial perceptions, attitudes, and behaviors. Therefore, anyone attempting to do business in a global setting should pay special attention to cultural factors.

2) For managers in the studied countries, the findings provide insight into the factors that lead to effective managerial practices and successful job performance. The managers should, on the one hand, develop sufficient self-knowledge to become an effective manager. He should ask himself what his own cultural values are and whether his subordinates share those values. If not, how to create an environment which is conducive to effective management. This is particularly important to companies in selecting, training, and motivating expatriate managers for assignments in Philippines and China. For example, by understanding the processes of how people are driven and motivated in a culture, we can gain important insights into why our subordinates work and react the way they do. We 
can also determine the most effective way to manage employees who come from diverse cultural backgrounds.

\section{Acknowledgements}

This work is supported by Social Science Foundation of Shandong Province under grant 19CDSJ07, Social Science Foundation of Shandong Province under grant 19CDNJ19, Key Subjects of Art Science in Shandong Province under grant CT201911167.

\section{Conflicts of Interest}

The authors declare no conflicts of interest regarding the publication of this paper.

\section{References}

Amante, M. S. V. (1994). Human Resource Approaches in the Philippines: Study of Japanese, Filipino-Chinese and Western-Owned Firms. UP SOLAIR.

Hofstede, G. (2001). Culture's Consequences. Thousand Oaks, CA: Sage.

Luo, Y. D. (2001). Strategic Response to a Volatile Environment: The Case of Cross-Cultural Cooperative Ventures. International Journal of Human Resource Management, No. 5.

Yan, Y. N. (2008). A Comparative Study of Human Resource Management Practices in International Joint Venture: The Impact of National Origin. The International Resource Management, No. 2.

Zhang, Y., Mathur, A., \& Neelankavil. (2000). Determinants of Managerial Performance: A Cross-Cultural Comparison of the Perceptions of Middle-Level Managers in Four Countries. Journal of International Business Studies, No. 1. 


\section{Appendix}

\section{Survey Questionnaires.}

Sir/Madam:

Good day:

Recently, Philippine companies start to extend their investments and gradually expand its capacity, and how to solve the cultural differences between these two countries is one of the vital and important issues in management. This research discusses cultural difference of working values of Chinese Managers and Filipino Managers from a case of Philippine Company in China. The framework of the survey is carefully designed to analyze the cultural differences of two countries being studied and do further research on how to better manage culture conflicts caused by these differences. We hope that you can kindly spare $20 \mathrm{mi}-$ nutes of your time to answer this survey.

Thank you for taking time answering these questions. This survey contains no private information and will remain confidential. This study is for research purposes only.

A study on Cultural Difference of Working Values of Chinese Managers and Filipino Managers: A case of Philippine Company in China

Survey Target:

Name: Age: Company:

I) Basic Information (Please answer the following)

1) I am a
a) Pure Filipino
b) Pure Chinese
c) Filipino born in China

d) Chinese born in Philippines

2) I have worked for
a) Less than 5 years
b) 5 - 10 years
c) 10 - 20 years
d) More than 20 years

3) I have worked in this company for
a) 1 - 2 year(s)
b) 2 - 5 years
c) 5 - 10 years
d) 10 - 20 years

e) More than 20 years

4) Where is your company located
a) Philippines
b) China

5) How influential do you think is your company in its line of industry

a) Not so influential b) Very influential c) Medium-scale enterprise

d) At the top of the industry

6) The company you work in belong to

a) Agricultural production (including agriculture, livestock breeding, fishery, forestry etc.)

b) Mining

c) Manufacturing of light industrial goods (such as garment, toy, household electrical appliances, etc.)

d) Manufacturing of heavy industrial products (such as vehicle and boat 
manufacturing, large-sized machinery and equipment manufacturing etc.)

e) Service Industry (such as commerce, transportation, catering, travel agency, education training, bank insurance securities, lawyer, doctor etc)

f) Others

\section{II) Working Values}

A) General questions: (You may choose more than one)

1) What do you think is the most important aspect that your job brings?

a) Provide basic needs (such as food and clothes)
b) Professional skills
c) Good working environment
d) Good interpersonal relationship
e) Career development
f) Personal interest
g) It allows me to get respect from others

2) Why do you submit to your superior?
a) Respect his(her) superiority
b) Respect his(her) professional expertise
c) $\mathrm{He}$ (she) can affect my career
d) have a good relationship with him(her)
e) be attracted to his/her charisma (or leadership or personality)
3) What's your long-term goal?
a) To have a stable salary
b) To save money to create own business
c) To maximize company benefits
d) To save up for a better future
e) To have personal and professional development
4) What will you do if you find some problems with work (i.e. waste of raw material, inefficiencies of the employees, unproductively etc.)?

a) Ignore them

b) Report to my superior if it is in relation with my work

c) Report to superior even if not related with my work

d) Report to superior and give some suggestions and advice

5) Who will you initially consult if you encountered some problems with work?
a) Solve with co-workers
b) Report to your direct superior

c) Consult with friends/family

B) True-False Question (Please put $\sqrt{ }$ or $x$ )

1) An employee should follow the majority's decision

2) The benefit of the group is more important than individual benefit

3) The more detailed the rules and regulations are the better

4) Aside from work relationship, I build a personal relationship with my superior

5) Working hard is a good deed

6) Working is just an aspect of my life

7) If I quit my job, I will feel sorry for my company

8) Children can borrow money from parents and do not have to pay them back even after getting married

9) Most of my salary should be saved in the bank

10) Time is gold

11) I can work in the same position all my life, as long as the salary increases gradually. 
12) If my colleague breaks the rules, and it isn't related to my work, I will not report it to my superior

\section{IV) Culture Conflicts}

A) (Please put your answers on the line, can have more than one answer)

1) Which of these factors affects your relationship with your foreign colleagues?
a) Language
b) Lifestyle
c) Religion
d) Views and opinions

e) Other aspects of culture

2) Why would you make friends with foreign colleagues?

a) I am interested in his(her) culture

b) it is good for my job when working with him(her)

c) I am interested in his(her) personality

3) The rules, regulation and policies of your company follows

a) Origin country of company

b) Local Company in the Philippines

c) Mix of both the origin country of the company and the local company

4) as for the problem of cultural conflicts

a) I don't experience that

b) It has some influence on company's operation but not serious

c) The company has a measure to deal with it

5) The right way to deal with the staff from different cultures is by

$\begin{array}{ll}\text { a) Treating them differently } & \text { b) Treating them equally }\end{array}$

6) What's the culture of your company at present?

a) Based on parent company's culture, maintain the parent company's culture, rules and regulations.

b) Based on culture of company where it is located, rules are made according to local habits, infusing local culture

c) Based on international commercial culture, rules made according to international general rules.

7) About cross-cultural communication,

a) Our company arranges only one set of meeting for staffs, in a language where everyone can understand. (i.e., using a secondary language such as English in the Philippines)

b) Our company arranges different sets of meetings for cross-cultural staffs in their primary language.

B) True-False Question (Please mark $\sqrt{ }$ or $\times$ on the line of the questions)

1) I can feel some cultural conflicts between the employees of the company

2) Cultural conflicts affect the working performance of the employees

3) The company arranges some meetings for staff with different cultural backgrounds to better communicate with them

C) Essay question (Please fulfill them by yourselves)

1) What preventive measures does the company have for the cultural conflicts? (such as to encourage the staff with different cultural backgrounds to 
communicate with others)

2) How does the company solve the problem of cultural conflicts? (such as to revise rules and regulations of the company) 